\title{
KONSEP PENDIDIKAN MENURUT MUHAMMAD NAQUIB AL-ATTAS DAN RELEVANSINYA DENGAN SISTEM PENDIDIKAN NASIONAL
}

\author{
Sri Syafa'ati \& Hidayatul Muamanah \\ Universitas Islam Negeri (UIN) Sunan Kalijaga Yogyakarta \\ srisyafaati7@gmail.com,hmuamanah@gmail.com
}

\begin{abstract}
Education is part of the life of society and nation to realize the ideals of the nation. So that Indonesian education activities need to be managed and organized into a means to realize the ideals of Indonesian education. This study aims to determine how the concept of education according to Syed Muhammad Naquib al-Attas and its relevance to the national education system. The approach used in the following research is a qualitative approach with the type of library research. Sources of data were obtained from books and journals related to research material. The results showed that Syed Muhammad Naquib al-Attas was a very intelligent and religious scientist. The concept of ta'dib or adab is used as an educational term which according to al-Attas is considered more appropriate, because it includes 'ilm and' amal at once. Syed Muhammad Naquib al-Attas divided knowledge into 2 types, namely the science of fardu 'ain and the science of fardu kifayah. This is also similar to the sharing of knowledge in education in Indonesia, namely religious sciences, social sciences and science
\end{abstract}

Keywords: Education, Muhammad Naquib al-Attas, Relevance, National Education System

\begin{abstract}
Abstrak : Pendidikan merupakan bagian dari kehidupan bermasyarakat serta berbangsa untuk mewujudkan cita-cita bangsa. Sehingga kegiatan pendidikan Indonesia perlu dikelola serta diorganisasikan menjadi sarana untuk mewujudkan cita-cita pendidikan negara Indonesia. Penelitian ini memiliki tujuan untuk mengetahui bagaimana konsep pendidikan menurut Syed Muhammad Naquib al-Attas dan relevansinya dengan sistem pendidikan nasional. Pendekatan yang digunakan dalam penelitian berikut adalah pendekatan kualitatif dengan jenis penelitian kepustakaan (library research). Sumber data diperoleh dari buku dan jurnal-jurnal terkait materi penelitian. Hasil penelitian menunjukkan bahwa Syed Muhammad Naquib al-Attas merupakan ilmuwan yang sangat cerdas sekaligus religius. Konsep ta'dib atau adab digunakan sebagai istilah pendidikan yang menurut al-Attas dianggap lebih tepat, sebab didalamnya sudah mencakup antara 'ilm dan 'amal sekaligus. Syed Muhammad Naquib al-Attas membagi ilmu ke dalam 2 jenis yakni ilmu fardu 'ain dan ilmu fardu kifayah. Hal tersebut juga serupa dengan pembagian ilmu dalam pendidikan di Indonesia yakni ilmu agama, ilmu sosial dan ilmu sains.
\end{abstract}

Kata Kunci : Pendidikan, Muhammad Naquib al-Attas, Relevansi, Sisdiknas 


\section{PENDAHULUAN}

Pendidikan merupakan bagian dari kehidupan bermasyarakat serta berbangsa untuk mewujudkan cita-cita bangsa. Sehingga kegiatan pendidikan nasional perlu dikelola serta diorganisasikan menjadi sarana untuk mewujudkan cita-cita nasional. ${ }^{1}$ Sedangkan pendidikan yang baik adalah pendidikan yang mampu mengembangkan dan mengasah kecerdasan majemuk pada anak didik, yakni tidak hanya mampu mengasah kecerdasan intelektualnya saja namun mencakup kecerdasan emosional, sosial serta spiritual agar mampu memberikan keseimbangan pada diri anak dari aspek individualitas kepada aspek sosialitas atau kepekaan dalam tatanan kehidupan bermasyarakat. ${ }^{2}$

Hal tersebut dilandaskan pada Undang-undang No 20 Tahun 2003 tentang Sistem Pendidikan Nasional yang menyatakan bahwa pendidikan berfungsi untuk mengembangkan segala potensi yang dimiliki subjek didik yang meliputi spiritual, pengendalian diri, kepribadian, kecerdasan, akhlak mulia serta berbagai keterampiran yang diperlukan bagi diri sendiri, masyarakat, bangsa serta negara. ${ }^{3}$ Pendidikan nasional yang dimaksud adalah pendidikan yang berlandaskan Pancasila serta UUD 1945 yang berakar pada nilai-nilai ajaran agama, kebudayaan bangsa dan sesuai dengan tuntutan perkembangan zaman. ${ }^{4}$

Namun era globalisasi selain memberi kontribusi yang luar biasa pada kesejahteraan manusia, disisi lain juga menjadikan manusia kehilangan jati diri (karakter) serta pegangan hidupnya yakni etika, moral, budaya dan bahkan agama ${ }^{5}$, karena manusia tidak mampu menyaring dan membentengi dirinya dari berbagai tantangan kehidupan yang tengah dihadapi.

Kejahatan serta pelanggaran terhadap nilai-nilai dan norma yang ada banyak dilakukan golongan yang seharusnya dapat memberi teladan kepada masyarakat luas,

\footnotetext{
1 Akhmad Hidayatullah Al Arifin, "IMPLEMENTASI PENDIDIKAN MULTIKULTURAL DALAM PRAKSIS PENDIDIKAN DI INDONESIA," Jurnal Pembangunan Pendidikan: Fondasi Dan Aplikasi Vol 1, No (2012), hlm. 73.

2 Sagaf. S. Pettalongi, "Islam Dan Pendidikan Humanis Dalam Resolusi Konflik Sosial," Cakrawala Pendidikan No 2 (2013), hlm. 177.

3 Heri Widodo, "POTRET PENDIDIKAN DI INDONESIA DAN KESIAPANNYA DALAM MENGHADAPI MASYARAKAT EKONOMI ASIA (MEA)," Cendekia Vol 13, No (2015), hlm. 297.

${ }^{4}$ Kemendikbud, “UU SISDIKNAS Nomor 20 Tahun 2003,” KEMENDIKBUD, 2013.

5 Maragustam, Filsafat Pendidikan Islam Menuju Pembentukan Karakter (Yogyakarta: FITK UIN Sunan Kalijaga, 2018), hlm. 245.
} 
misalnya golongan terpelajar, pengusaha dan pejabat dalam menjalankan peran serta fungsinya. Apabila keadaan ini dikaitkan dengan pendidikan, maka menunjukkan rapuhnya landasan moral serta nilai-nilai spiritual yang ada dalam sistem pendidikan. Harapan terbangunnya moral dan nilai dari tujuan pendidikan masihlah jauh. ${ }^{6}$

Hal inilah yang membuat para pemikir khususnya Islam merumuskan kembali format pendidikan Islam dalam upaya pembaharuan pendidikan Islam. Dari sekian banyak para pemikir Islam, yakni salah satu diantaranya Syed Muhammad Naquib alAttas yang merupakan pemikir Islam kontemporer yang memiliki concern tinggi terhadap kemunduran peradaban umat Islam serta konsep pendidikannya yang tergolong fundamental. Sehingga sosok dan pemikirannya menarik untuk ditelaah. Berawal dari kegelisahannya tentang degradasi dalam pendidikan Islam yang disebabkan oleh modernisasi yang akhirnya membuat dirinya merumuskan kembali format pendidikan Islam. ${ }^{7}$

Berdasarkan latar belakang permasalahan tersebut, dalam artikel ini akan membahas bagaimana relevansi pendidikan Muhammad Naquib al-Attas terhadap sistem pendidikan nasional. Dengan tujuan (1) untuk mengetahui biografi Syed Muhammad Naquib al-Attas, (2) mengetahui konsep pendidikan yang dikemukaan oleh Syed Muhammad Naquib al-Attas, (3) mengetahui relevansi konsep pendidikan Islam yang dikemukakan oleh Syed Muhammad Naquib al-Attas bagi sistem pendidikan nasional.

\section{METODE PENELITIAN}

Dalam penelitian ini pendekatan yang digunakan adalah pendekatan kualitatif. Kualitatif adalah penelitian yang mengungkapkan, menganalisis, lalu menginterpretasi dari objek yang ada pada keadaan tertentu. Penyajian data dilakukan dengan tidak menggunkan statistik. ${ }^{8}$ Penelitian ini menggunakan jenis penelitian kepustakaan (library

${ }^{6}$ Halimatus Sa'diyah, "Spiritualitas Pendidikan Islam Perspektif Syed Muhammad Naquib AlAttas," Tadris Vol 8, No (2013), hlm. 158.

7 Yunita Furi Aristyasari, "Pemikiran Pendidikan Islam Syed Muhammad Naquib Al-Attas," Hermenia: Jurnal Kajian Islam Interdsipliner Vol 13, No (2013), hlm. 256.

8 Muri Yusuf, Metode Penelitian Kualtatif, Kunatitaf Dan Penelitian Gabunga (Jakarta: PredanaMedia Grup, 2014). 
research) yaitu penelitian yang digunakan untuk memecahkan problem yang bersifat konseptual-teoretis, baik tentang tokoh pendidikan atau konsep pendidikan tertentu seperti tujuan, metode dan kurikulum. ${ }^{9}$

Teknik pengumpulan data dalam penelitian ini penulis mengambil sumber data primer dari beberapa buku yang relevan dengan pokok bahasan tulisan buku tentang pemikiran tokoh, dan buku-buku lainnya yang berkaitan dengan judul makalah. Selain itu, sebagai sumber data sekunder penulis mengambil sumber data dari literasi lain seperti jurnal-jurnal yang relevan untuk memperkaya bahasan dalam tulisan ini.

\section{Biografi}

Prof. DR. Syed Muhammad Naquib al-Attas lahir di Bogor, Jawa Barat pada tanggal 5 September 1931. Jika dilihat dari silisahnya Prof. DR. Syed Muhammad Naquib al-Attas, ayahnya yang bernama Syed Ali bin Abdullah al-Attas berasal dari Saudi Arabia yakni dari keturunan ulama dan ahli bidang tasawuf. Dari garis ibunya, ibunya adalah Syarifah Raguan al-Idrus berasal dari keturunan kerabat raja-raja pada kerajaan Sunda Sukapura, Jawa Barat. Sehingga dari sana dapat diketahui bahwa Syed Muhammad Naquib al-Attas adalah keturunan darah biru yang memiliki semangat religius yang sangat kental dan mendalam. Dengan latar belakang keluarganya yang demikian memberikan pengaruh pada pendidikan Syed Muhammad Naquib al-Attas. Pendidikan agama ia peroleh dari keluarga ibunya yang berada di Bogor, sedangkan untuk pengetahuan bahasa, sastra dam kebudayaan Melayu didapatkan dari keluarga yang berada di Johor. ${ }^{10}$

Pada usia 5 tahun Syed Muhammad Naquib al-Attas diajak pindah oleh orang tuanya ke Malaysia, di Malaysia ia bersekolah di Ngee Heng English School Johor hingga usianya sampai 10 tahun (1936-1941). Pada masa penjajahan Jepang di Indonesia al-Attas dan keluarganya kembali ke Jawa Barat. Kemudian ia melanjutkan pendidikannya di sukabumi yakni di Madrasah al-Urwah al-Wutsqa pada tahun 1941-

${ }^{9}$ Rofik Mujahid Dkk, Panduan Penulisan Skripsi (Yogyakarta: UIN Sunan Kalijaga, 2017).

${ }_{10}$ Wan Mohd Nor Wan Daud, Filsafat Dan Praktik Pendidikan Islam Syed M. Naquib Al-Attas, Terj. Hamid Fabmy Dke (Bandung: Mizan, 1998). 
1945, sebuah lembaga pendidikan yang menggunakan Bahasa Arab Sebagai Bahasa pengantarnya. ${ }^{11}$

Tahun 1945 saat perang dunia II telah selesai, pada tahun berikutnya yakni 1946, Syed Muhammad Naquib al-Attas melanjutkan pendidikannya di Johor. Ia melanjutkan pendikannya di Bukit Zahrah School, kemudian di English College tahun 1946- 1951. Pada tahun 1951 Syed Muhammad Naquib al-Attas berhasil menyelesaikan pendidikannya, kemudian Ia mendaftarkan pada dinas tentara sebagai perwira kadet dalam askar Malaysia-Inggris. Berkat kepiawaiannya Syed Muhammad Naquib al-Attas diikutkan dalam pendidikan militer. Pendidikan yang pertama di Eaton Hall, Chester Wales, selanjutnya Syed Muhammad Naquib al-Attas melanjutkan di Royal Military Academy, Sandhurst Inggris (1952-1955). Setelah tamat dari Royal Military Academy, al-Attas ditugaskan sebagai pegawai kantor di resimen tentara kerajaan Malaya, Federasi Malaya. Pada tugas ini berlangsung tidak lama. Setelah malaysia merdeka pada tahun 1957 Syed Muhammad al-Naquib al-Attas mengundurkan diri dari dinas militer dan mengembangkan potensinya dalam bidang ilmu pengetahuan. Dengan minat yang ia miliki tersebut al-Attas melanjutkan pendidikan ke Universitas Malaya, Kuala Lumpur masuk pada fakultas Kajian Ilmu-Ilmu Sosial (Sosial Sciencs Studies). Saat studi S1-nya Syed Muhammad Naquib al-Attas berhasil menyelesaikan dua buku. Buku pertama yang berhasil ia selesaikan ialah "Rangkaian Ruba'iyat" dan buku keduanya adalah "Some Aspects of Sufism as Understood and Practised Among the Malaya". Karena buku keduanya sangat berharga sehingga pemerintahan Kanada, melalui Canada Council Fellowship, memberinya beasiswa untuk belajar di Universitas McGill yakni di institut of Islamic Studies pada tahun 1960-1962. Gelar Mater of Art (M.A) diperolahnya dari Universitas McGill dengan tesis yang berjudul Raniri and the Wujudiyah of $17^{\text {th }}$ Century Acheh lulus dengan nilai yang sangat memuaskan. Setahun setelah kelulusannya Syed Muhammad Naquib al-Attas melanjutkan pendidikannya ke Universitas London yakni di SOAS (School of Oriental and African Studies) di kampus inilah Syed Muhammad alNaquib al-Attas mendapatkan gelar Doctor of Phylosophy (Ph.D) dengan predikat

${ }^{11}$ Ibid., hlm. 46-50 
Cumlaude dalam bidang Filsafat Islam dan Kesusasteraan Melayu Islam setelah berhasil mempertahankan disertasinya yang berjudul The Mysticism of Hamzah Fansuri. ${ }^{12}$

Setetah menyelesaikan pendidikannya di Inggris pada tahun 1965, Syed Muhammad Naquib al-Attas melanjutkan pengabdian di Universitas Malaya. Di Universitas Malaya inilah Syed Muhammad Naquib al-Attas mulai menunjukkan kehebatannya dan kecemerlangan, ia memperoleh jabatan sebagai kepala jurusan Sastra pada Fakultas Kajian Melayu. Kemudian pada tahun 1968-1970 Syed Muhammad Naquib al-Attas mendapat jabatan di Universitas yang sama yakni sebagai Dekan Fakultas Sastra. Karir Syed Muhammad Naquib al-Attas sangat maju pada tahun 1970 menjadi salah satu pendiri senior pada salah satu Universitas terbaik di Malaysia yakni Universitas Kebangsaan Malaysia (UKM). Delapan tahun berselang yakni tepatnya pada tahun 1978 Syed Muhammad Naquib al-Attas menjadi pendiri sekaligus rektor International Institute of Islamic Thought and Civilization (ISTAC) di Malaysia. ${ }^{13}$

Jumlah makalah yang disampaikan oleh Syed Muhammad Naquib al-Attas dalam kegiatan ilmiahnya yakni sebanyak 400 makalah. Makalah tersebut disampaikan di banyak negara yakni Amerika, negara-negara di Eropa, Jepang, dan beberapa negara Islam termasuk Indonesia. Pada acara konferensi pendidikan Islam yang diselenggarakan di Mekah tahun 1977, Syed Muhammad Naquib Attas menjadi pembicara sebagai peserta yang aktif. Hal yang paling membanggakan adalah konferensi tersebut terinspirasi dari gagasan yang dikemukakan oleh Syed Muhammad Naquib alAttas yang mengemukakan bahwa persoalan yang paling penting dan mendesak pada umat Islam yakni masalah ilmu pengetahuan. Gagasan tesebut ia tulis pada surat yang disampaikan Sekretariat Islam tahun 1973, di Jeddah. ${ }^{14}$

Berkat sumbangsihnya dalam pendidikan Islam kontemporer tersebut Dato Seri Anwar Ibrahim pada tahun 1993 menunjuk Syed Muhammad al-Naquib al-Attas sebagai pemegang pertama Abu Hamid al-Ghazali Chair of Islamic Thought (Kursi Kehormatan Abu Hamid al-Ghazali dalam Studi Pemikiran Islam) di ISTAC. Penghargaan selanjutnya juga berturut-turut datang yakni dari raja Hussein pada tahun

12 Ibid.

13 Ibid., hlm 50-54

14 Kemas Badaruddin, Filsafat Pendidikan Islam; Analisis Pemikiran Prof. DR. Syed Mubammad AlNaquib Al- Attas, (Yogyakarta: pustaka Pelajar, 2009). 
1994, raja dari Yordania ini mengangkatnya sebagai anggota Royal Academy of Jordan. Selanjutnya tahun 1995 Universitas Khartoum, Sudan menganugerahinya gelar doktor kehormatan (D. Litt) di bidang seni. ${ }^{15}$

\section{Konsep Pendidikan}

Dalam dunia pendidikan, khususnya pendidikan Islam dikenal tiga rangkaian istilah yang sering digunakan untuk menunjuk pendidikan Islam yaitu tarbiyah, ta'lim dan ta'dib yang keseluruhannya dipakai secara bersamaan. Menurut al-Attas istilah "tarbiyah" dalam bahasa arab, atau "education" dalam bahasa Inggris yang berasal dari bahasa Latin "educare" tidaklah tepat jika diperuntukkan bagi istilah pendidikan. ${ }^{16}$

Tarbiyah dalam bahasa arab berasal dari kata rabba yang berkaitan dengan proses pertumbuhan, pemberian makan serta pengasuhan (untuk menjadikan dewasa). Sehingga istilah ini tidak terbatas hanya pada manusia, namun juga meliputi tanaman dan hewan yang perlu pemeliharaan untuk menjadi dewasa dan meningkat. Secara universal, alQur'an juga menggunakan istillah ini untuk merujuk fungsi ini, karena Rabb yang Melestarikan Alam Semesta serta Pemiliknya (rabb). Dari penjelasan tersebut, al-Attas menyimpulkan bahwa makna tarbiyah yang dimaksudkan sebagai pemeliharaan, pemberian makan, dan hal-hal yang hanya terbatas pada pertumbuhan fisik, sedangkan hal-hal yang berkaitan dengan fungsi akal ('aql) yang merupakan bagian yang sangat penting bagi manusia tidak termasuk di dalamnya. ${ }^{17}$ Inilah salah satu sebab yang mendasari al-Attas yang menyatakan bahwa kata tarbiyah tidak tepat digunakan untuk menunjukkan pendidikan dalam arti Islam, karena pendidikan dalam Islam hanya diperuntukkan bagi manusia semata. ${ }^{18}$

${ }^{15}$ Ibid., Wan Mohn Nor Wan Daud, Filsafat..., hlm. 54.

16 Abdul Ghoni, "Pemikiran Pendidikan Naquib Al-Attas Dalam Pendidikan Islam Kontemporer," Lentera: Kajian Keagamaan, Keilmuan Dan Teknologi Vol 3, No (2017), hlm. 199-200.

${ }^{17}$ Hamid Fahmy Zarkasyi et al., "Reading Al-Attas' Ta'dīb as Purpose of Islamic University," in International Conference on Science, Technology, and Environment (Yogyakarta, 2019), 3.

18 Ghoni, "Pemikiran Pendidikan Naquib Al-Attas Dalam Pendidikan Islam Kontemporer," 2017, hlm. 199. 
Sedangkan istilah ta'lim walaupun maknanya lebih luas daripada tarbiyah, yaitu informasi, nasehat, bimbingan, ajaran serta latihan ${ }^{19}$, menurutnya juga tidak tepat untuk memaknai pendidikan, yang dirasa maknanya masih sempit daripada pendidikan. Tampaknya hal tersebut didukung oleh pendapat Rasyid Ridha yang memaknai ta'lim sebagai proses transmisi berbagai ilmu pengetahuan jiwa individu tanpa ada batasan serta ketentuan tertentu. Pendapat al-Attas ini didasarkan dengan merujuk pada surat alBaqarah ayat 2 yang berbunyi "wa yu'allimukumul kitaaba wal bikmata”, yang menjelaskan tentang aktivitas Rasulullah mengajarkan al-Qur'an kepada kaum muslim. Sehingga ta'lim terlalu sempit apabila digunakan untuk istilah pendidikan karena terbatas hanya pengajaran semata.

Kemudian al-Attas menawarkan istilah yang menurutnya lebih tepat mengacu pada makna pendidikan yakni ta'dib. Ia melihat bahwa adab merupakan salah satu misi yang dibawa Rasulullah SAW sebagaimana sabda beliau "Tuhanku telab mendidikku, dan dengan demikian telah menjadikan pendidikanku yang terbaik.". ${ }^{20}$ Al-Attas juga berpendapat bahwa dalam ta'dib terdapat konsep-konsep pendidikan dan proses kependidikan dalam Islam, yaitu konsep-konsep makna (ma'na), ilmu (ilm), keadilan ('adl), kebijaksanaan (bikmah), tindakan ('ama), kebenaran atau ketetapan yang benar (haqq), nalar (nuthq), jiwa $(n a f s)$, hati (qalb), pikiran dan intelek ('aql). Dari seluruh konsep-konsep tersebut saling berkaitan dalam pola yang bermakna, yang memproyeksikan konsep pendidikan khas Islam. AL-Attas menyimpulkan dari berbagai konsep-konsep tersebut memusatkan makna-maknanya hanya pada satu konsep kunci utama yang terkandung dalam istilah adab atau ta'dib, yang didalamnya sudah mencakup 'ilm dan 'amal sekaligus. Dengan alasan inilah orang-orang bijak, para cerdik cendekia serta para sarjana muslim terdahulu mengombinasikan 'ilm, 'amal dan ta'dib menjadi kombinasi harmonis sebagai pendidikan. $^{21}$

Penekanan yang diinginkan oleh al-Attas untuk mengganti tarbiyah menjadi ta'dib tersebut merupakan salah satu upayanya untuk merekonstruksi kembali arah serta

${ }^{19}$ Irma Novayani, "Islamisasi Ilmu Pengetahuan Menurut Pandangan Syed M. Naquib Al-Attas Implikasi Terhadap Lembaga Pendidikan International Institute Of Islamic Thought Civilization (ISTAC)," Jurnal AL-Muta'aliyah STAI Darul Kamal NW Kembang Kerang Vol 1, No (2017), hlm. 81.

${ }^{20}$ Aristyasari, "Pemikiran Pendidikan Islam Syed Muhammad Naquib Al-Attas.", hlm. 262.

${ }^{21}$ Mohammad David El Hakim and Eni Fariyatul Fahyuni, "Pendidikan Islam Dalam Perspektif Syed Naquib Al-Attas Dan Relevansinya Bagi Pengembangan Pendidikan Islam Di Indonesia," Islamika: Jurnal Keislaman Dan Ilmu Pendidikan Vol 2, No1 (2020), hlm. 58-59. 
tujuan pendidikan yang dikehendaki al-Attas. Senada dengan pendapat Azyumardi Azra yang menyatakan bahwa proses pengajaran dalam pendidikan saat ini hanyalah mengisi kognitif saja, sedangkan aspek dalam pembentukan kepribadian dan watak tidak diperhatikan. Oleh sebab itu, ia menawarkan solusi berupa arah rekonstrusi pendidikan Islam, salah satunya dengan merumuskan kembali makna pendidikan dan menyatakan kesetujuannya terhadap konsep ta'dib yang diajukan oleh al-Attas. ${ }^{22}$

\section{Konsep Tujuan Pendidikan Islam}

Al-Attas beranggapan bahwa tujuan dari pendidikan Islam ialah menanamkan kebajikan dalam "diri manusia” sebagai manusia serta sebagai individu. Tujuan akhirnya adalah untuk menghasilkan manusia yang baik dari aspek kehidupan material sekaligus spiritualnya, yang menitikberatkan pada pembentukan aspek pribadi individu serta mengharapkan pembentukan masyarakat ideal. Masyarakat yang baik atau ideal ini sesungguhnya terbentuk dari kepribadian masing-masing individu yang baik, karena pada hakikatnya masyarakat merupakan kumpulan dari individu-individu.

Sehingga dapat disimpulkan bahwa al-Attas menghendaki pendidikan Islam untuk mampu mencetak manusia yang baik secara universal (insan kamil), yang orientasinya pada dua dimensi sekaligus yaitu, sebagai hamba Allah dan sebagai khalifah di bumi. ${ }^{23}$ Dengan harapan yang tinggi yakni menginginkan pendidikan dapat mencetak manusia paripurna (insan kamil) yang bercirikan universalitas dalam wawasan serta ilmu pengetahuan yang bercermin kepada ketauladanan Nabi Muhammad SAW. Untuk mencapai tujuan tersebut, menurutnya pendidikan Islam harus mengacu kepada aspek afektif (moral-transendental), sekaligus aspek kognitif (sensual logis) serta psikomotorik (sensual empirik). ${ }^{24}$ hlm. 200.

${ }^{22}$ Ghoni, "Pemikiran Pendidikan Naquib Al-Attas Dalam Pendidikan Islam Kontemporer.", ${ }^{23}$ Sa'diyah, "Spiritualitas Pendidikan Islam Perspektif Syed Muhammad Naquib Al-Attas.", hlm. 168.

${ }^{24}$ Novayani, "Islamisasi Ilmu Pengetahuan Menurut Pandangan Syed M. Naquib Al-Attas Implikasi Terhadap Lembaga Pendidikan International Institute Of Islamic Thought Civilization (ISTAC).”, hlm. 82-83. 


\section{Sistem Pendidikan Islam}

Sesuai dengan tujuan dan konsep pendidikan Islam yang dideskripsikan al$\operatorname{Attas}^{25}$, maka sistem pendidikan Islam haruslah mengandung unsur adab (etika) serta ilmu pengetahuan, sebab inti dari pendidikan ialah membentuk watak serta akhlak mulia yang mempu mengembangkan ilmu pengetahuan yang bermanfaat bagi diri sendiri sekaligus seluruh umat. Sistem pendidikan yang diformulasikannya ialah dengan mengintegrasikan ilmu, yakni Islam menghadirkan serta mengajarkan dalam proses pendidikan tidak hanya ilmu-ilmu agama, akan tetapi juga ilmu-ilmu rasional, intelek dan filosofis. Langkah integrasi ini dengan cara ilmu pengetahuan dan teknologi terlebih dahulu dilandasi dengan pertimbangan nilai-nilai serta ajaran agama. Sebab pendidikan Islam masih mengalami keterjajahan oleh konsepsi pendidikan Barat. Adanya dikotomi ilmu, sehingga tidak adanya integrasi ilmu yang seharusnya diwujudkan untuk mengembangkan ilmu pengetahuan yang berwawasan dan bernuansa Islami. ${ }^{26}$

\section{Kurikulum}

Kurikulum pendidikan Islam dalam pandangan al-Attas berangkat dari pandangannya bahwa manusia bersifat dualistik. Pertama, untuk memenuhi kebutuhan yang berdimensi permanen dan spiritual (fardhu 'ain), dan yang kedua, yang dapat memenuhi kebutuhan material-emosional (fardhu kifayah). Pemahaman serta pelaksanaan yang tepat terhadap kategori ilmu pengetahuan fardhu 'ain (kewajiban bagi diri sendiri) dan fardhu kifayah (kewajiban bagi masyarakat) yang akan memastikan terwujudnya kesejahteraan individu dan sosial. Walaupun ilmu pengetahuan kedua (fardhu kifayab) berkaitan langsung dengan masyarakat, namun peranan ilmu pertama (fardhu 'ain) mempunyai pengaruh signifikan secara tidak langsung. Dimensi pertama dijadikan nilainilai dasar bagi pengembangan dimensi selanjutnya, yang mencakup aspek keilmuan, life skill dan berbagai aspek lainnya. Sedangkan apabila aspek keilmuan dikembangkan dengan berlandaskan pada aspek keilmuan pertama, maka dapat menjadi media untuk

${ }^{25}$ Zulham Effendi, "Pemikiran Pendidikan Muhammad Naquib Al-Attas," Jurnal Waraqat Vol 2, No (2017), hlm. 129.

26 Muhammad Sakti Garwan, "Urgensi Islamisasi Ilmu Syed Naquib Al-Attas Dalam Upaya Deskonstruksi Ilmu Hermeneutika Al-Qur'an,” Substantia Vol 21, No (2019), hlm. 135-136. 
memahami dan menghayati Tuhan dalam bentuk sikap empirik ketaatan kepada segala peraturan Allah swt. ${ }^{27}$

Berikut ruang lingkup Ilmu fardhu 'ain yang meliputi:

1. Ilmu al-Qur'an yang terdiri dari tafsir dan ta'wil

2. Al-Sunnah yang terdiri dari perjalanan hidup, risalah dan sejarah Nabi, hadits dan perawinya

3. Asy-syariah terdiri dari undang-undang dan hukum, prinsip-prinsip serta pengamalan Islam (Islam, Iman dan Ihsan)

4. At-Taubid (teologi) yang terdiri dari perbincangan tentang Tuhan, sifat-sifat-Nya, esensi-Nya, nama-nama-Nya dan perbuatan-Nya

5. At-Tasawuf yang terdiri dari psikolog, kosmologi, ontologi, unsur-unsur dalam filsafat Islam

6. Linguistik atau ilmu bahasa yang terdiri dari bahasa Arab, tata bahasa, leksikografi dan kesustrasaan.

Untuk kategori ilmu yang kedua yakni fardhu kifayah ruang lingkupnya berkaitan dengan ilmu rasional, intelektual dan falsafah yang seluruhnya terangkum dalam ilmu kemanusiaan, ilmu tabi'i, ilmu terapan dan teknologi. ${ }^{28}$ Ilmu-ilmu rasional, intelektual dan filosofis pada bagian ilmu fardu kifayah menurut Syed Muhammad Naquib al-Attas pada tiap-tiap cabang ilmu harus diresapi dengan unsur-unsur dan konsep-konsep kunci Islam, setelah unsur-unsur dan konsep-konsep kunci asing dibersihkan dari semua cabangnya. Proses pembuangan dari unsur-unsur dan konsep-konsep kunci asing inilah yang kemudian disebut dengan "islamisasi". ${ }^{29} \mathrm{Al}$ Attas tidak membatasi ruang lingkup ilmu fardhu kifayah, sebab pada prinsipnya pengetahuan itu sendiri ialah sifat Tuhan.

Kemudian menurut al-Attas struktur ilmu pengetahuan dan kurikulum haruslah mampu menggambarkan manusia sekaligus hakekatnya. Dengan adanya pembedaan keilmuan ini bukan untuk mendikotomi ilmu, namun menjadikannya kesatuan yang

${ }^{27}$ Effendi, "Pemikiran Pendidikan Muhammad Naquib Al-Attas.", hlm. 130.

28 Putri Lestari, Nurul Iman, and Katni, "Pemikiran Pendidikan Islam Syed Muhammad Naquib Al-Attas (Tinjauan Paradigmatik Dan Implementatif Konsep Ta"dib Dalam Pembelajaran Agama Islam Pada Tingkat SMA/MA)," Jurnal Mahasiswa Tarbawi: Journal on Islamic Education Vol 3, No (2019): 26.

${ }^{29}$ Ghoni, "Pemikiran Pendidikan Naquib Al-Attas Dalam Pendidikan Islam Kontemporer.", hlm. 205. 
dinamis untuk membebaskan manusia dan menumbuhkan potensi manusia. Kebebasan dalam akademik yang dimaksud bukan kebebasan tanpa batas, akan tetapi kebebasan akademik dimaknai sebagai dasar pencapaian dan penyebarluasan adab setinggi-tingginya sesuai kemampuan. ${ }^{30}$

\section{Metode Pendidikan}

Dikutip dari Muhammad Ardiansyah dkk, menurut Wan Mohd Nor Wan Daud metode yang dipraktikkan oleh al-Attas tidaklah banyak ditemukan dalam karyanya. Tentu dalam hal ini al-Attas berbeda dari kebanyakan pakar pendidikan modern yang identik membahas metode pendidikan dalam karya mereka. Hal tersebut dikarenakan alAttas memandang bahwa konten pendidikan sangat penting dan menjadi prioritas tertinggi daripada metode. Namun, bukan berarti al-Attas menganggap metode dalam pendidikan itu tidak penting. Berdasarkan tujuan pendidikan yang diterangkan olehnya yaitu penamanan pendidikan kesopanan, kesopanan yang dimaksud ialah sebagai metode yang tepat untuk mencapai pengetahuan dan kemudian menerapkannya. Dalam studinya yang lebih mendalam, Wan Mohd Nor Wan Daud merangkum beberapa metode pengajaran yang digunakan oleh al-Attas yaitu, metode Tauhid, metode diskusi, pencitraan, bercerita, penugasan, metode nasehat, hadiah dan hukuman, serta metode peran model. ${ }^{31}$

Akan tetapi disisi lain, telah diketahui bahwa pendidikan serta epistemologi Islam yang dijelaskan secara tajam dan dipraktekkan oleh al-Attas ialah metode tauhid dalam ilmu pendidikan. Metode tauhid ini bertujuan untuk menyelesaikan problem dikotomi yang salah, contohnya antara aspek obyektif dan subyektif ilmu pengetahuan. Menurut al-Attas yang dikutip oleh Halimatus Sa'diyah, menjelaskan bahwa yang obyektif dan subyektif tidaklah dapat dipisahkan, karena merupakan aspek dari realitas yang sama sehingga antara satu dengan yang lainnya saling melengkapi. Tujuan dari pendidikan yang integral akan terwujud apabila metode ini diterapkan, sebab metode ini menciptakan keseimbangan dalam pemahaman serta penghayatan subjek didik sehingga mampu mengamalkan ilmunya dengan baik di masyarakat dengan landasan nilai-nilai

${ }^{30}$ Effendi, "Pemikiran Pendidikan Muhammad Naquib Al-Attas.", hlm. 132.

31 Muhammad Ardiansyah et al., "The Concept of Adâb by Syed Muhammad Naquib Al-Attas and Its Relevance to Education in Indonesia," Ibn Khaldun Journal of Social Science Vil 1, No (2019), hlm. 58. 
agama. Namun apabila dalam pelaksanaan pendidikan yang integral tidak terpenuhi, maka tujuan yang dicita-citakan sebagaimana yang dikemukakan al-Attas juga tidak akan tercapai. Sehingga dalam pendidikan harus terpenuhi keselarasan, kesatuan, atau unitifikasi antara aspek lahir dan batin sekaligus, misalnya antara aspek kognitif dengan aspek afektif, aspek emosional-spiritual dan juga aspek psikomotorik untuk mendukung terjadinya aktivitas. ${ }^{32}$

\section{Relevansi Konsep Pendidikan Muhammad Naquib al-Attas dengan Sisdiknas}

Konsep pendidikan menurut Muhammad Naquib al-Attas merupakan suatu proses penanaman sesuatu dalam diri manusia dengan cara bertahap sehingga membimbingnya ke arah pengenalan terhadap Allah swt Sang Maha Pencipta. Pengakuan tanpa adanya pengenalan adalah sebuah kesiasiaan. Dengan kata lain harus ada kesesuaian antar ilmu dan amal karena dari keduanya haus berjalan beriringan. Menurut al-Atas, subjek didik harusnya mengetahui tentang dirinya sendiri. Pemahaman subjek didik akan dirinya sendiri juga akan membuat subjek didik memahami dari mana ia berasal, dimana dia berada dan akan kemana ia kelak. Sehingga dapat memahami tentang dirinya sendiri, dapat memahami lingkungan dan dengan pemahaman itulah ia dapat memahami Tuhannya. Dan konsekuensi logisnya ia akan sempurna menjadi khalifah di bumi yang tujuan akhirnya adalah menjadi manusia yang terbaik atau dalam istilah al-Attas adalah insan kamil. ${ }^{33}$ Pemikiran al- attas tersebut sesuai dengan arah tujuan pendidikan di Indonesia yang dimuat dalam UU No. 20 Tahun 2003 pasal 3 Tentang Sistem Pendidikan Nasional, tujuan pendidikan nasional adalah untuk mengembangkan potensi peserta didik agar menjadi manusia yang beriman dan bertakwa kepada Tuhan Yang Maha Esa, berakhlak mulia, sehat, berilmu, cakap, kreatif, mandiri, dan menjadi warga negara yang demokratsis dan bertanggung jawab. ${ }^{34}$

Dalam hal kurikulum pendidikan, al-Attas merumuskan bahwa pendidikan yang ada hendaknya pendidikan itu harus terpadu dan terintegrasi. Sehingga pendidikan

${ }^{32}$ Sa'diyah, "Spiritualitas Pendidikan Islam Perspektif Syed Muhammad Naquib Al-Attas.", hlm. 174-175.

33 Kemas Badaruddin, Filsafat ..., hlm. 36-39.

34 “'Undang-Undang Nomor 20 Tahun 2003 Tentang Sistem Pendidikan Nasional Pasal 3.,” n.d. 
sebaiknya tidak hanya mengajarkan tentang pendidikan agama namun juga mengajak ilmu-ilmu pengetahuan rasional, intelektual dan filsafat. ${ }^{35}$ Lebih rinci al-Attas membagi ilmu kedalam dua jenis yakni ilmu fardu kifayah dan bersifat fardu 'ain. Ilmu fardu 'ain adalah ilmu yang bersumber dari Allah swt sedangkan ilmu yang bersifat fardu kifayah adalah ilmu-ilmu yang didapat dari usaha manusia yang meliputi ilmu intelektual, rasional dan filsafat. Seperti yang sudah dijelaskan di atas, pembagian ilmu oleh al-Attas tersebut bukan berarti mendikotomi ilmu, namun hanya menginformasikan bahwa ilmu sumbernya ada dua macam tersebut. Kemudian selain itu, menjadikan keduanya kesatuan yang dinamis untuk membebaskan manusia dan menumbuhkan potensi manusia. Kebebasan dalam akademik yang dimaksud bukan kebebasan tanpa batas, akan tetapi kebebasan akademik dimaknai sebagai dasar pencapaian dan penyebarluasan adab setinggi-tingginya sesuai kemampuan. ${ }^{36}$

Sedangkan dalam sistem pendidikan yang ada di Indonesia menerapkan adanya dikotomi ilmu pengetahuan, yang terdiri dari ilmu agama, ilmu-ilmu umum yang meliputi ilmu alam, ilmu sosial, dan ilmu lainnya. Dikotomi tersebut jelas terlihat pada praktek dua model lembaga pendidikan yang ada di Indonesia. Model pertama ialah model sekolah-sekolah umum seperti SD, SMP, SMA/SMU. Sedangkan model yang kedua yaitu model sekolah-sekolah dengan ciri khas agama seperti MI, MTs, dan MA. ${ }^{37}$ Tentu dari keduanya terlihat proporsi ilmu agama yang diajarkan lebih banyak pada sekolah agama dibandingkan sekolah-sekolah umum. Sehingga kesannya sekolah agama berfokus pada ilmu agama dan ilmu tertinggal, sedangkan sekolah umum fokusnya ilmu umum dan ilmu agamanya tertinggal. Tentunya hal ini bertolak belakang dari tujuan pendidikan yang dicita-citakan Indonesia yakni menginginkan terlahirnya insan kamil.

Akan tetapi seiring perkembangannya, lembaga pendidikan di Indonesia mulai menerapkan integrasi keilmuan, misalnya muncul lembaga pendidikan terpadu yang menerapkan pembelajaran integrasi atau terpadu. Yang didalamnya tidak memisahkan antara ilmu fardhu 'ain dengan ilmu fardhu kifayah yang keduanya diharapkan mampu

36 Effendi, "Pemikiran Pendidikan Muhammad Naquib Al-Attas.”, hlm. 132.

${ }^{37}$ Suyatno, "Sekolah Islam Terpadu; Filsafat, Ideologi, Dan Tren Baru Pendidikan Islam Di Indonesia," Jurnal Pendidikan Islam Vol II, No (2013), hlm. 359. 
membentuk insan paripurna atau insan kamil sekaligus sebagai khalifah di muka bumi ini. $^{38}$

Dan sesuai pada apa yang tertuang dalam UU No 20 Tahun 2003 tentang Sisdiknas dan PP No 19 Tahun 2005 tentang SNP mengamanatkan bahwa kurikulum pada jenjang dan jenis pendidikan dikembangkan serta disusun sendiri oleh masingmasing satuan pendidikan, yakni dengan mengembangkan kurikulum yang disesuaikan dengan karakteristik serta kebutuhan dan potensi siswa, masyarakat dan lingkungannya. ${ }^{39}$ Lembaga pendidikan di Indonesia pun mulai merombak sistem pendidikannya yakni kurikulum, dengan integrasi keilmuan yang diharapkan mampu mengembangkan segala potensi dan mampu menghadapi perkembangan zaman yang tujuannya untuk menuju insan kamil tersebut, sesuai dengan pemikiran al-Attas.

\section{KESIMPULAN}

1. Syed Muhammad al-Naquib al-Attas lahir di Bogor, Jawa Barat pada tanggal 5 September 1931.

2. Tujuan dari pendidikan Islam ialah menanamkan kebajikan dalam "diri manusia" sebagai manusia serta sebagai individu. Tujuan akhirnya adalah untuk menghasilkan manusia yang baik dari aspek kehidupan material sekaligus spiritualnya, yang menitikberatkan pada pembentukan aspek pribadi individu serta mengharapkan pembentukan masyarakat ideal. Masyarakat yang baik atau ideal ini sesungguhnya terbentuk dari kepribadian masing-masing individu yang baik, karena pada hakikatnya masyarakat merupakan kumpulan dari individu-individu.

3. Relevansi konsep pendidikan yang telah dikemukkan oleh Syed Muhammad alNaquib al-Attas memiliki kesamaan dengan sistem pendiikan nasional yakni pada tujuan pendidikan dan kurikulum pendidikan yakni dengan membagi ilmu pengetahuan.

${ }^{38}$ Ibid., hlm. 362-363.

39 Tatik Sudiati, "Peningkatan Kinerja Guru Dalam Menetapkan Kriteria Ketuntasan Minimal Melalui Workshop,” Ilmu Pendidikan: Jurnal Kajian Teori Dan Praktik. Kependidikan Vol 3, No (2018), hlm. 231. 


\section{DAFTAR PUSTAKA}

Ardiansyah, Muhammad, Didin Hafidhuddin, Endin Mujahidin, and Nirwan Syafrin. "The Concept of Adâb by Syed Muhammad Naquib Al-Attas and Its Relevance to Education in Indonesia." Ibn Khaldun Journal of Social Science Vil 1, No (2019): 58.

Arifin, Akhmad Hidayatullah Al. "IMPLEMENTASI PENDIDIKAN MULTIKULTURAL DALAM PRAKSIS PENDIDIKAN DI INDONESIA." Jurnal Pembangunan Pendidikan: Fondasi Dan Aplikasi Vol 1, No (2012): 73.

Aristyasari, Yunita Furi. "Pemikiran Pendidikan Islam Syed Muhammad Naquib AlAttas." Hermenia: Jurnal Kajian Islam Interdsipliner Vol 13, No (2013): 256.

Dkk, Rofik Mujahid. Panduan Penulisan Skripsi. Yogyakarta: UIN Sunan Kalijaga, 2017.

Effendi, Zulham. "Pemikiran Pendidikan Muhammad Naquib Al-Attas." Jurnal Waraqat Vol 2, No (2017): 129.

Garwan, Muhammad Sakti. "Urgensi Islamisasi Ilmu Syed Naquib Al-Attas Dalam Upaya Deskonstruksi Ilmu Hermeneutika Al-Qur'an.” Substantia Vol 21, No (2019): 135-36.

Ghoni, Abdul. "Pemikiran Pendidikan Naquib Al-Attas Dalam Pendidikan Islam Kontemporer." Lentera: Kajian Keagamaan, Keilmuan Dan Teknologi Vol 3, No (2017): 199-200.

Hakim, Mohammad David El, and Eni Fariyatul Fahyuni. "Pendidikan Islam Dalam Perspektif Syed Naquib Al-Attas Dan Relevansinya Bagi Pengembangan Pendidikan Islam Di Indonesia." Islamika: Jurnal Keislaman Dan Imu Pendidikan Vol 2, No1 (2020): 58-59.

Kemas Badaruddin. Filsafat Pendidikan Islam; Analisis Pemikiran Prof. DR. Syed Mubammad Al-Naquib Al- Attas,. Yogyakarta: pustaka Pelajar, 2009.

Kemendikbud. “UU SISDIKNAS Nomor 20 Tahun 2003.” KEMENDIKBUD, 2013.

Lestari, Putri, Nurul Iman, and Katni. "Pemikiran Pendidikan Islam Syed Muhammad Naquib Al-Attas (Tinjauan Paradigmatik Dan Implementatif Konsep Ta dib Dalam Pembelajaran Agama Islam Pada Tingkat SMA/MA)." Jurnal Mahasiswa Tarbawi: Journal on Islamic Education Vol 3, No (2019): 26.

Maragustam. Filsafat Pendidikan Islam Menuju Pembentukan Karakter. Yogyakarta: FITK UIN Sunan Kalijaga, 2018.

Novayani, Irma. "Islamisasi Ilmu Pengetahuan Menurut Pandangan Syed M. Naquib AlAttas Implikasi Terhadap Lembaga Pendidikan International Institute Of Islamic Thought Civilization (ISTAC)." Jurnal AL-Muta'aliyah STAI Darul Kamal NW Kembang Kerang Vol 1, No (2017): 81.

Pettalongi, Sagaf. S. "ISLAM DAN PENDIDIKAN HUMANIS DALAM RESOLUSI KONFLIK SOSIAL.” Cakrawala Pendidikan No 2 (2013): 177.

Sa'diyah, Halimatus. "Spiritualitas Pendidikan Islam Perspektif Syed Muhammad Naquib Al-Attas." Tadris Vol 8, No (2013): 168.

Sudiati, Tatik. "Peningkatan Kinerja Guru Dalam Menetapkan Kriteria Ketuntasan Minimal Melalui Workshop." Ilmu Pendidikan: Jurnal Kajian Teori Dan Praktik 
Kependidikan Vol 3, No (2018): 231.

Suyatno. "Sekolah Islam Terpadu; Filsafat, Ideologi, Dan Tren Baru Pendidikan Islam Di Indonesia." Jurnal Pendidikan Islam Vol II, No (2013): 359.

"Undang-Undang Nomor 20 Tahun 2003 Tentang Sistem Pendidikan Nasional Pasal 3.," n.d.

Wan Mohd Nor Wan Daud. Filsafat Dan Praktik Pendidikan Islam Syed M. Naquib AlAttas, Terj. Hamid Fahmy Dkk. Bandung: Mizan, 1998.

Widodo, Heri. "POTRET PENDIDIKAN DI INDONESIA DAN KESIAPANNYA DALAM MENGHADAPI MASYARAKAT EKONOMI ASIA (MEA)." Cendekia Vol 13, No (2015): 297.

Yusuf, Muri. Metode Penelitian Kualtatif, Kunatitaf Dan Penelitian Gabunga. Jakarta: PredanaMedia Grup, 2014.

Zarkasyi, Hamid Fahmy, Jarman Arroisi, Muhammad Taqiyuddin, and Mohammad Syam'un Salim. "Reading Al-Attas' Ta'dīb as Purpose of Islamic University." In International Conference on Science, Technology, and Environment, 3. Yogyakarta, 2019. 